\title{
Glacial-Holocene calcareous nannofossils and paleoceanography in the northern South China Sea
}

\author{
Kuo-Yen Wei ${ }^{*}$, Tien-Nan Yang, Chi-Yue Huang \\ Department of Geology, National Taiwan University, Taipei, Taiwan
}

Received 1 June 1996; accepted 1 December 1996

\begin{abstract}
Last glacial to Holocene paleoceanography of the northern South China Sea was inferred from nannofossil variations and several hydrographic proxies from a piston core, SCS90-36 $\left(17^{\circ} 59.70^{\prime} \mathrm{N}, 111^{\circ} 29.64^{\prime} \mathrm{E}\right.$, water depth $\left.2050 \mathrm{~m}\right)$. The upper part of the sedimentary sequence (dated 15.5 to $1.2 \mathrm{ka}$ ) provided a high-resolution record whereas part of the sediments older than $15.5 \mathrm{ka}$ was lost due to erosion. A correspondence analysis of the nannofossil succession suggests that the paleoceanography developed in four stages. The first stage (26-13.3 ka) has a fairly well-preserved diverse nannoflora dominated by Gephyrocapsa and Florisphaera profunda. The floral composition together with high concentration of ketones $\left(C_{37}\right)$ and organic carbon indicates high surface-water fertility. The second stage, the deglacial period (13.3-10.7 ka), had an increased surface-water turbidity and a stronger influence of Pacific open-ocean waters as evidenced by the decrease of Florisphaera profunda and increase of Emiliania huxleyi, respectively. A preservation peak of calcareous microfossils centered at $12 \mathrm{ka}$ correlates to the global preservation event of Termination I. The third stage, early Holocene $(10.7-4.4 \mathrm{ka})$, is marked by a gradual increase of $F$. profunda and small placolith taxa at the expense of $E$. huxleyi. The floral composition indicates that conditions were more oligotrophic compared to the pre-Holocene. The preservation of nannofossils became progressively worse, indicating a rise of the nannofossil lysocline. In sediments deposited at 5.5 and $4 \mathrm{ka}$, nannofossil preservation improves, probably reflecting a local cooling event. During the last stage, from 4.4 to 1.2 ka, E. huxleyi, Umbilicosphaera and large Reticulofenestra increased their relative abundance to replace small placoliths. Further stratification of the surface water column may have been responsible for this floral succession.
\end{abstract}

Keywords: Pleistocene; Holocene; South China Sea; nannofossil; paleoceanography

\section{Introduction}

The extensive development of glaciers in polar areas during the last glacial maximum (LGM) resulted in a sea-level drop by $120 \mathrm{~m}$ (Fairbanks, 1989). Most straits that bound the South China Sea (SCS) became too shallow to allow exchange of waters

\footnotetext{
* Corresponding author. Tel.: +886-2-3691143; fax: +866-2-

3636095; e-mail: weiky@ccms.ntu.edu.tw
}

between the South China Sea and the open oceans. The Bashi Strait, located between Taiwan and Luzon Island (Fig. 1), with a sill depth of $2500 \mathrm{~m}$, was the only passageway to the West Philippine Sea during the last glacial. The exposure of continental shelves, especially in the southern part, also caused a 1/5 reduction of the surface area of the South China Sea (Wang, 1990). The lower sea level might also have caused the Kuroshio to shift offshore, east of its current position (Ujiie et al., 1991; Ahagon 


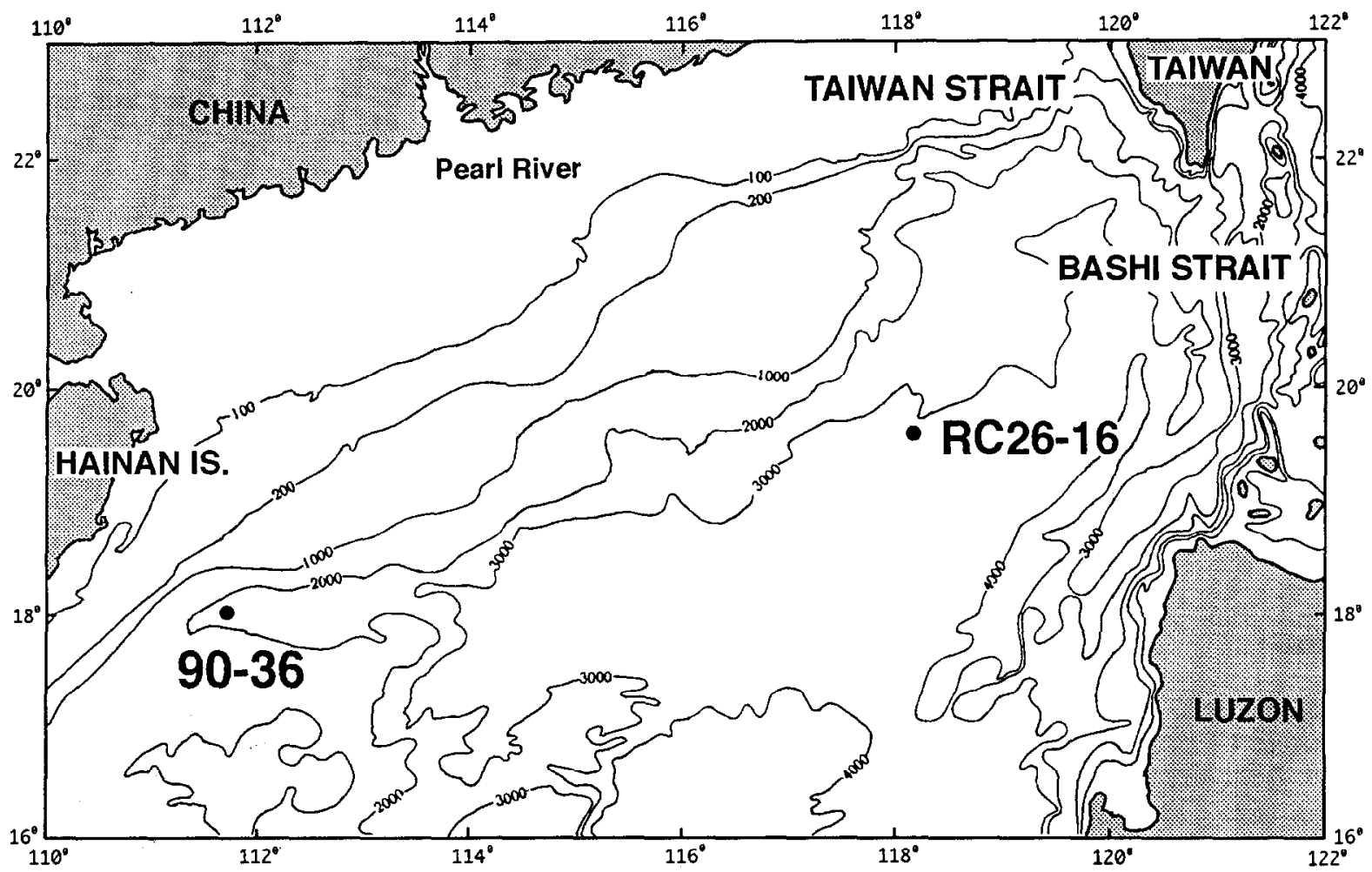

Fig. 1. Locations of Core SCS90-36 studied and Core RC26-16 mentioned in the text.

et al., 1993), putting the South China Sea under a stronger influence of the Continent Coastal Current (Wang and Wang, 1990). In the northwestern Pacific, the Kuroshio Front advanced southward during the last glacial (Moore et al., 1980; Thompson, 1981). The Kuroshio Front then moved northward at about 13-10 ka (Chinzei et al., 1987), synchronous with the post-glacial warming of the North Atlantic Ocean (Duplessy et al., 1981). There were, however, two intervening retreats of the Kuroshio Front to the south during the post-glacial period; the first was at 11-10 $\mathrm{ka}$, corresponding to the Younger Dryas Event while the second took place after $5.5 \mathrm{ka}$. Both events were associated with brief cooling (Chinzei et al., 1987).

The winter sea surface temperatures (SSTs) in the northern part of the South China Sea were estimated to be $4-6^{\circ} \mathrm{C}$ lower than today on average (at RC26-16 by Wei et al., 1996; at SCS $90-36$ by Huang et al., 1997; and to the south, near the Mindoro Island, by Miao et al., 1994). The summer SSTs were estimated to be quite similar to today's or $2^{\circ} \mathrm{C}$ lower (Wei et al., 1996; Miao et al., 1994; Huang et al.,
1997). The larger seasonal temperature contrast has been attributed to reduced surface water exchanges across the straits and to a stronger winter monsoon (Miao et al., 1994). This stronger winter monsoon during the glacial might also have resulted in better mixing of the surface water and so have induced higher biological production (Huang et al., 1997). A subsequent drop of surface productivity during the transition from the glacial to the postglacial has also been documented in other western Pacific lowlatitude areas and in the SCS (Herguera and Berger, 1991; Herguera, 1992; Thunell et al., 1992). Both the mixing rate and nutrient concentration of the deep waters were lowered during the glacial-postglacial transition (Herguera and Berger, 1994).

Huang et al. (1997) documented a rich set of last glacial to Holocene paleoceanographic proxies and interpretations from the piston core SCS90-36 located on the northern slope of the South China Sea (Fig. 1). Here we document a quantitative study of the calcareous nannofossil assemblages from the same core. We attempt to integrate the nannofossil 
evidence with the other available data to further illustrate the deglacial warming and climatic fluctuations during the Holocene in the northern South China Sea.

\section{Samples and procedures}

The piston core SCS 90-36 was recovered from $17^{\circ} 59.70^{\prime} \mathrm{N}, 111^{\circ} 29.64^{\prime} \mathrm{E}$, at a water depth of $2050 \mathrm{~m}$ on the southern slope of the Xisha Trough (Fig. 1). The sequence consists of fine silty clay without any detectable turbidite layers. The chronology of the sequence was constrained by eight radiocarbon datings of planktic foraminifera using accelerator mass spectrometry (AMS) (Fig. 2; Huang et al., 1997). The radiocarbon age of the bottom of the studied sequence is about $26 \mathrm{kyr}$. The extremely low sedimentation rates $(<2 \mathrm{~cm} / \mathrm{kyr})$ in the lowermost part (Fig. 2), however, have led us to suspect that most of the sediments deposited prior to $15.5 \mathrm{ka}$ were lost due to erosion.

Samples were taken every $3 \mathrm{~cm}$ from the top $103 \mathrm{~cm}$ of the core, corresponding to a temporal resolution of $\sim 500 \mathrm{yr}$ per sample for the Holocene and $\sim 200 \mathrm{yr}$ for the deglacial period. A total of 32 samples were analyzed. At least 700 coccoliths were identified and tallied per sample under a Zeiss Photomicroscope at a magnification of $1250 \times$. Several samples were examined under a scanning electron microscope to facilitate taxonomic identifications.

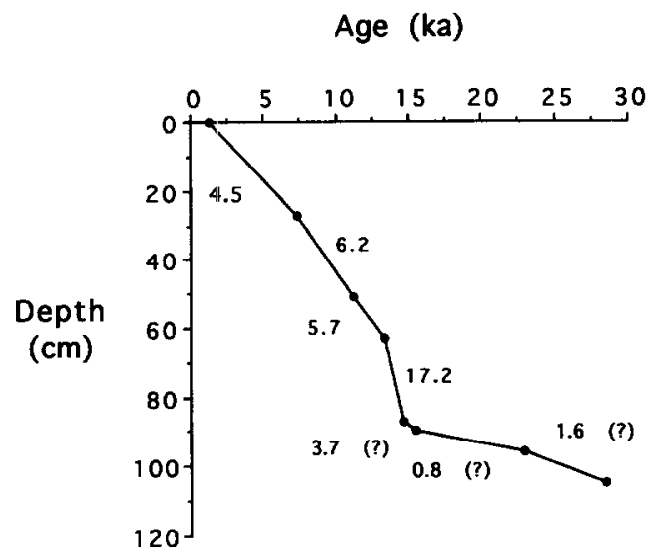

Fig. 2. Depth-age diagram of Core SCS90-36, showing sedimentation rates estimated from eight AMS ${ }^{14} \mathrm{C}$ dates of planktic foraminifera.
Table 1

List of tallied nannofossils

Calcidiscus leptoporus ${ }^{\mathrm{a}}$ (Murray and Blackman) Loeblich and Tappan, 1978

Calcidiscus macintyrei ${ }^{\mathrm{b}}$ (Bukry and Bramlete) Loeblich and Tappan, 1978

Calciosolenia murrayi Gran, 1912

Ceratolithus cristatus ${ }^{\text {a }}$ Kamptner, 1950

Coronocyclus nitescens $^{b}$ (Kamptner) Bramlette and Sullivan, 1961

Crenalithus sp. Chen, 1978

Cricolithus jonesi Cohen, 1965

Dictyococcites perplexa Burns, 1975

Dictyococcites productus (Kamptner) Backman, 1980

Discoaster spp. ${ }^{\text {b }}$

Emiliania huxleyi (Lohmann) Hay and Mohler, 1967

Florisphaera profunda profunda Okada and Honjo, 1973

Florisphaera profunda elongata Okada and McIntyre, 1979

Gephyrocapsa caribbeanica Boudreaux and Hay, 1967

Gephyrocapsa oceanica Kamptner, 1943, see Matsuoka and Okada, 1989

Helicosphaera carteri carteri ${ }^{\text {a }}$ (Wallich) Kamptner, 1954

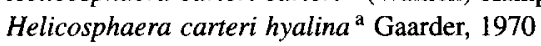

Helicosphaera carteri wallichii ${ }^{a}$ (Lohmann) Okada and McIntyre, 1977

Neosphaera coccolithomorpha ${ }^{\mathfrak{c}}$ Lecal-Schlauder, 1951

Oolithotus fragilis ${ }^{\circ}$ (Lohmann) Okada and McIntyre, 1977

Pontosphaera discopora Schiller, 1925

Pontosphaera japonica (Takayama) Burns, 1973

Pontosphaera multipora (Kamptner) Roth, 1970

Pseudoemiliania lacunosa ${ }^{\mathrm{b}}$ (Kamptner) Gartner, 1969

Reticulofenestra haqii Backman, 1978

Reticulofenestra minuta Roth, 1970

Reticulofenestra minutula (Gartner) Haq and Berggren, 1978

Rhabdosphaera clavigera ${ }^{\mathrm{a}}$ Murray and Blackman 1898

Rhabdosphaera longistylis ${ }^{\text {a }}$ Schiller, 1925

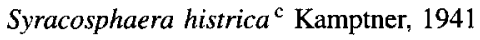

Syracosphaera lamina ${ }^{\mathrm{C}}$ Lecal-Schlauder, 1951

Syracosphaera pulchra ${ }^{\mathrm{c}}$ Lohmann, 1902

Syracosphaera spp. ${ }^{\mathrm{c}}$

Thoracosphaera spp. ${ }^{\mathrm{c}}$

Umbellosphaera irregularis ${ }^{\mathrm{c}}$ Paasche, 1955

Umbellosphaera tenuis ${ }^{c}$ (Kamptner) Pausche, 1955

Umbilicosphaera sibogae ${ }^{\text {a }}$ (Weber-van Bosse) Gaarder, 1970

${ }^{a}$ Dissolution-resistant.

${ }^{\mathrm{b}}$ Reworked species.

${ }^{\mathrm{c}}$ Dissolution-susceptible.

The nannofossil taxa tallied are listed in Table 1. Taxonomic diagnoses and nomenclatural notes on some selected species are given in Appendix A.

To monitor the preservation state of the nannofossil assemblages, a dissolution index, defined as the ratio of resistant species to resistant + suscep- 
tible species, was calculated. We adopted Roth and Coulbourns' ranking (Roth and Coulboum, 1982) of the north tropical Pacific nannofossil dissolution susceptibility to assign the various species into the two categories (Table 1). Only minor and rare species were included in the calculation in order to avoid being overwhelmed by dominant species and hopefully to reduce artifacts introduced by factors other than dissolution.

A rich set of paleoceanographic proxies, including weight percentage of carbonate and organic carbon, relative abundances of planktic foraminifera, carbon and oxygen isotopic ratios of planktic and benthic foraminifera, $U_{37}^{\mathrm{k}^{\prime}}$ index of long-chain ketones as well as abundance of $\mathrm{C}_{37}$ ketones, were measured by Huang et al. (1997).

\section{Multivariate analysis}

To recognize the down-core nannofossil variation pattern, we applied a multivariate ordination technique, detrended correspondence analysis (DCA) (Hill and Gauch, 1980), to the nannofloral count data. This method allows taxa and samples to be ordinated simultaneously and therefore shows the relationship between them. The DCA is a modification of regular correspondence analysis to eliminate the 'arch effect' that normally distorts the projection of data points on the first axis. This modified method can adjust the scores so that the data points are more linear along the first axis and more evenly spread out. The DCA assumes that the samples come from a gradient in which different variables (taxa) characterize different parts of the gradient. In applying this method, we explicitly seek an ordination pattern along the chronological axis. In other words, we are trying to identify taxa which show most age-dependent variation and therefore characterize the various stages in the paleoceanographic development.

All reworked taxa and taxa with relative abundances less than $1 \%$ were excluded. To reduce skewness and to improve normality of data distribution, the original percentage data were natural log transformed prior to analysis. The transformation also moderately weights the minor and rare taxa relative to the dominant taxa so that variations in the minor taxa will not be overwhelmed by the dominant ones.

\section{Results and interpretations}

Calcareous nannofossils are fairly common throughout the studied section and display a diverse assemblage with good preservation. Between 28 and 39 species/subspecies were recorded per sample. Representative species are illustrated in Plates I-IV. The nannofossil assemblages were dominated by three taxa: Gephyrocapsa spp., Emiliania huxleyi and a deep dwelling species, Florisphaera profunda (Fig. 3). The latter two are considered to be pelagic species, increasing their relative abundances with water depth, whereas Gephyrocapsa has a preference for neritic environments in the marginal seas of the western Pacific (Chen and Shieh, 1982; Okada, 1983, 1992; Cheng, 1992; Chen and Huang, 1995). The compositions of the studied samples fall generally in the bathypelagic province of open sea in the western Pacific as defined by Okada (1983). The occurrence of Syracosphaera, Rhabdosphaera, Oolithotus, Ceratolithus and Umbellosphaera, although rare in abundance, is typical for the bathypelagic environments in the western Pacific marginal seas (Chen and Shieh, 1982; Okada, 1983; Wang and Samtleben, 1983; Cheng, 1992).

The correspondence analysis yielded a quite interpretable pattern (Fig. 4). The first two axes account for 44 and $11 \%$ of the data variation, respectively. Samples exhibit a well-phased chronological ordination. The floral succession can be subdivided into four stages: Stage I, dated 25.9-13.3 ka, represented by the glacial assemblage; Stage II, from 13.3 to 10.7 $\mathrm{ka}$, marked by the deglacial flora; Stage III, 10.7-4.4 $\mathrm{ka}$, the early Holocene; and Stage IV, 4.4-1.2 ka, the late Holocene. The glacial and deglacial samples are clustered and distributed on the left half of the first axis, with a progressive upward migration along the second axis. In contrast, the Holocene samples occupy the right half of the first axis and show a downward transition along the second axis. The boundaries of stages are characterized by major shifts in the data trajectories (Fig. 4a). The characteristic nannofossils of each stage can be found in the corresponding positions on the projection of the species scores on the two eigen-axes (Fig. 4b).

The glacial stage (Stage I, 25.9-13.3 ka) is characterized by the dominance of Gephyrocapsa and 


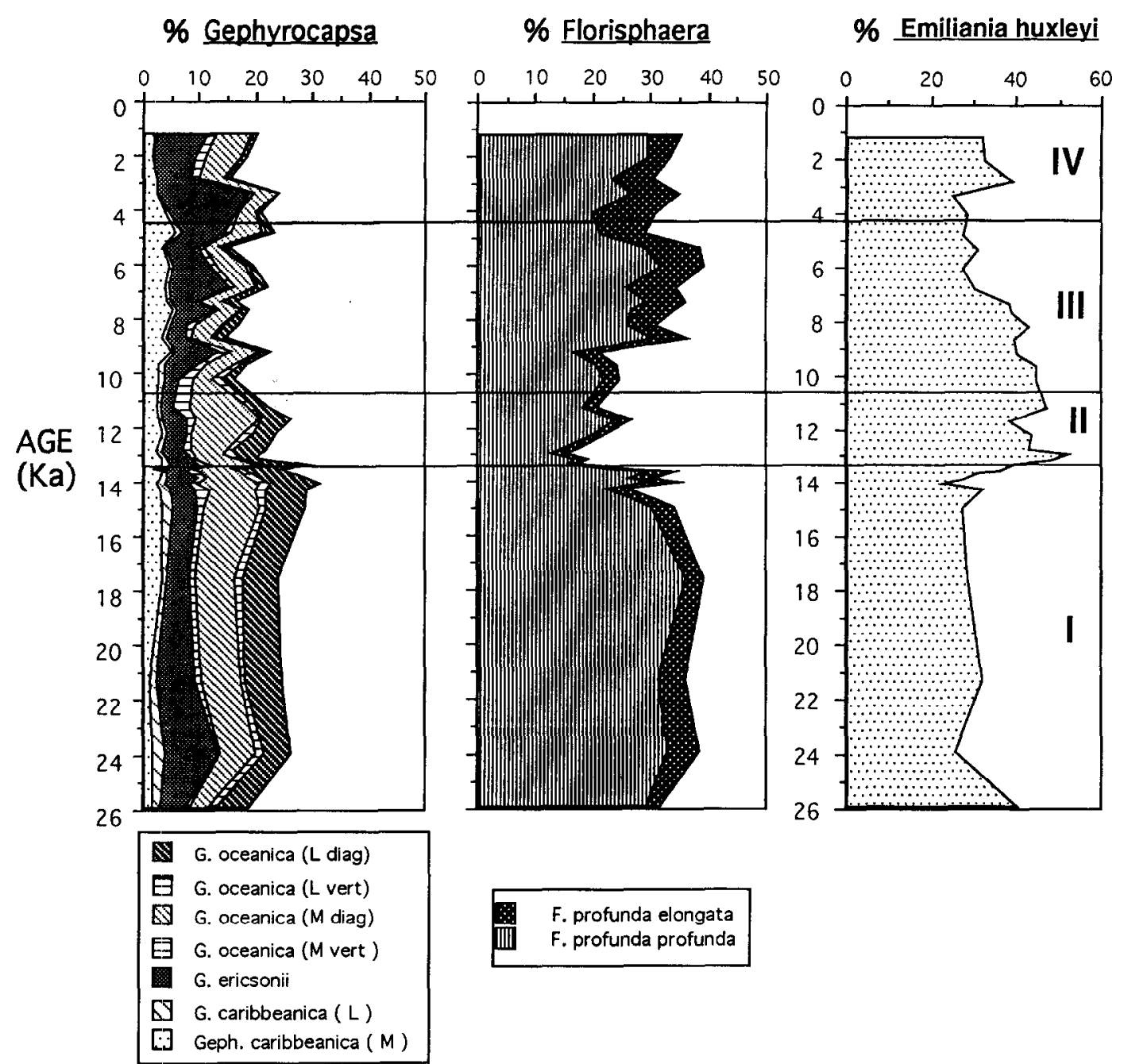

Fig. 3. Downcore variation of the relative abundances of three dominant nannofossil taxa. Horizontal lines mark the boundaries of four stages recognized from the correspondence analysis shown in Fig. 4.

Florisphaera (Fig. 3). The diverse flora and more frequent appearance of dissolution-susceptible taxa (such as Umbellosphaera, Syracosphaera and Calciosolenia murrayi) relative to other stages suggests that the nannofossil preservation in the glacial interval is generally better. Since the intermediate and deep waters of the SCS during the glacials were only exchanged with Pacific Intermediate waters through the Bashi Strait, the bottom water chemistry at the studied site is believed to be mainly governed by that of the Pacific Intermediate waters. The good preservation of carbonate during glacials was due to reduced production of North Atlantic Deep Waters
(NADW) and probably the formation of nutrientdepleted Pacific intermediate waters at that time (Thunell et al., 1992).

Gephyrocapsa tends to dominate in highly fertile waters. Winter (1982) found that the distribution of G. oceanica was closely related to the concentration of phosphate in the Gulf of Elat ('Aqaba), Red Sea. The abundance of $G$. oceanica in the northern South China Sea also shows a decreasing trend with concentration of phosphate from south to north (Cheng, 1992). The predominance of large Gephyrocapsa in the nannoflora (Fig. 6), in association with the high concentration of organic carbon and ketones $\left(\mathrm{C}_{37}\right)$ 


\section{Correspondence Analysis}

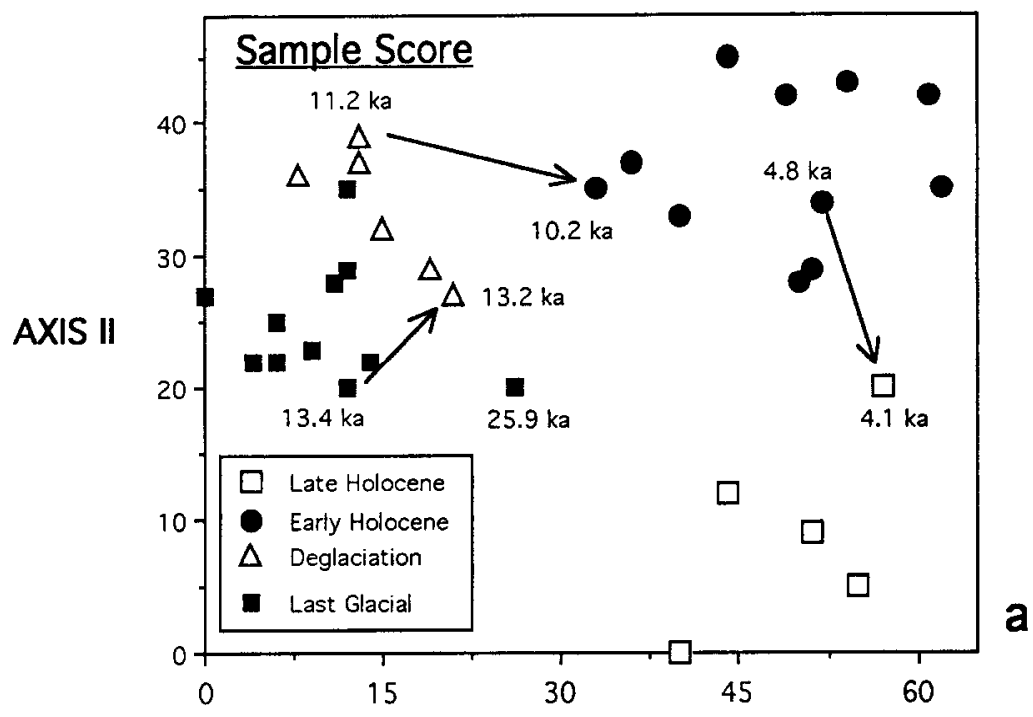

AXIS I

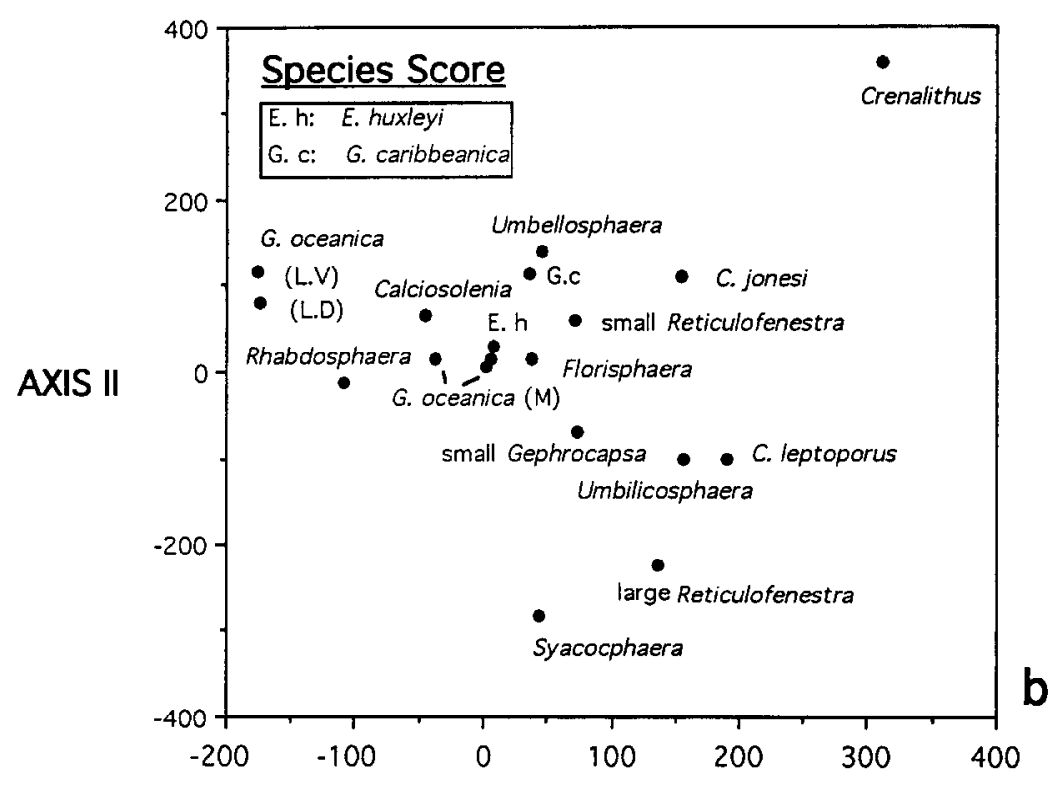

\section{AXIS I}

Fig. 4. Scores of samples (upper panel) and species (lower panel) on the plane of the first two eigen-axes resulting from detrended correspondence analysis.

(Fig. 7; Huang et al., 1997) suggests the existence of a less maritime environment with high fertility conditions during the last glacial. The surface-water productivity in the SCS was estimated to be two times higher during the last glacial maximum than in the Holocene (Thunell et al., 1992). Furthermore, 
the high frequency of Rhabdosphaera spp. (Fig. 6), a characteristic cold-subtropical species (Winter et al., 1994), is also indicative of colder conditions in comparison to the post-glacial stages II-IV.

The increase in Emiliania huxleyi during the deglacial interval (Stage II, 13.3-10.7 ka, Fig. 3) indicates an increasing influence of the open-ocean waters due to the concomitant rise of global sea level (Fairbanks, 1989). At the same time, in the northwestern Pacific the Kuroshio Front moved northward (Chinzei et al., 1987), synchronous with the post-glacial warming of the North Atlantic Ocean (Duplessy et al., 1981).

The major drop of Florisphaera between 13.3 and 9 ka (Fig. 3) may either indicate a rise of the nutricline, or an increase of turbidity of the surface waters. Among the various coccolithophorids, Florisphaera is distinctive in living in the lower euphotic zone with low light and high nutrients. Its habitat is restricted to waters below $100 \mathrm{~m}$ and warmer than $10^{\circ} \mathrm{C}$ (Okada and Honjo, 1973; Honjo and Okada, 1974; Okada and McIntyre, 1979). Molfino and McIntyre (1990a,b) proposed a conceptual model that when the nutricline is deeper the growth of Florisphaera would be enhanced relative to surface dwelling coccolithophorids. The relative abundance of Florisphaera therefore is indicative of fluctuation of the nutricline in the euphotic zone; the higher the relative abundance, the deeper the nutricline. On the other hand, Ahagon et al. (1993) argued that this model is only applicable to the equatorial areas where the nutricline depth is mainly governed by the equatorial divergence. Ahagon et al. (1993) instead documented that in the marginal seas around the Japanese islands, there was a close relationship between the $F$. profunda abundance and seawater transparency (Secchi depth). Given the proximity of the northern South China Sea to the continent and the relatively high sedimentation rates of the sequence, we follow Ahagon et al. (1993) in suggesting that the decrease of the relative abundance of Florisphaera profunda is an indication of increasing turbidity of the surface waters rather than a shallowing of the nutricline. Increasing turbidity is probably caused by increased lateral transportation of fine sediments carried by the newly established Continent Coastal Current flowing through Taiwan Strait and continental shelves off the Pearl River (Zhujiang) mouth
(Pinxian Wang, pers. commun., 1995). The rise of the sea level due to the global meltwater discharges during the deglacial period (13.0-11.5 and 10.0-9.0 ka, Fairbanks, 1989) would have caused the Taiwan Strait submerged and become a passageway through which the Continent Coastal Current flew southward and flushed previously deposited sediments from continental shelves. The fine particles were probably transported by contour currents, forming nepheloid layers with high turbidity.

On the other hand, the timing (13-9 ka) of the drop of the relative abundance of $F$. profunda is consistent with that recorded in the equatorial Atlantic (Molfino and McIntyre, 1990b). If this reduction of $F$. profunda abundance is a global phenomenon, occurring not only in the Atlantic equatorial divergence but also in the western Pacific marginal seas, then it might suggest either a global shallowing of nutricline depth, or a global increase of cloudiness (resulting in less penetration of sunlight). Such a global mechanism, however, is difficult to imagine.

The intervals dated between 12.5 and $11.5 \mathrm{ka}$ showed the best nannofossil preservation, containing many Umbellosphaera and Oolithotus fragilis (Figs. 5 and 6). Planktic foraminifera also showed relatively good preservation in the same interval (Fig. 5; Huang et al., 1997). The dissolution intensity of the bottom water during the deglacial time is inferred to be the lowest throughout the past 15.5 kyr (Fig. 5), synchronous with the global deglacial preservation spike of Termination I (Berger, 1977). Boyle (1988) suggested that during the deglaciation carbonate preservation was enhanced. During Termination I the circulation of the intermediate waters of the NSCS already appears closely linked with that of the Pacific intermediate waters, whose corrosiveness, in turn, was governed by the relative strength of North Atlantic Deep Water and Antarctic Bottom Water. The occurrence of this preservation spike agrees with the 'nutrient redistribution model' of Boyle (1988).

Another significant change during the deglacial period is shown by Gephyrocapsa. The total abundance of Gephyrocapsa (Fig. 3) continuously decreased from the glacial level through the deglacial to the late Holocene. Furthermore, within the Gephyrocapsa complex, the dominance of the large forms of $G$. oceanica was first displaced by the medium- 

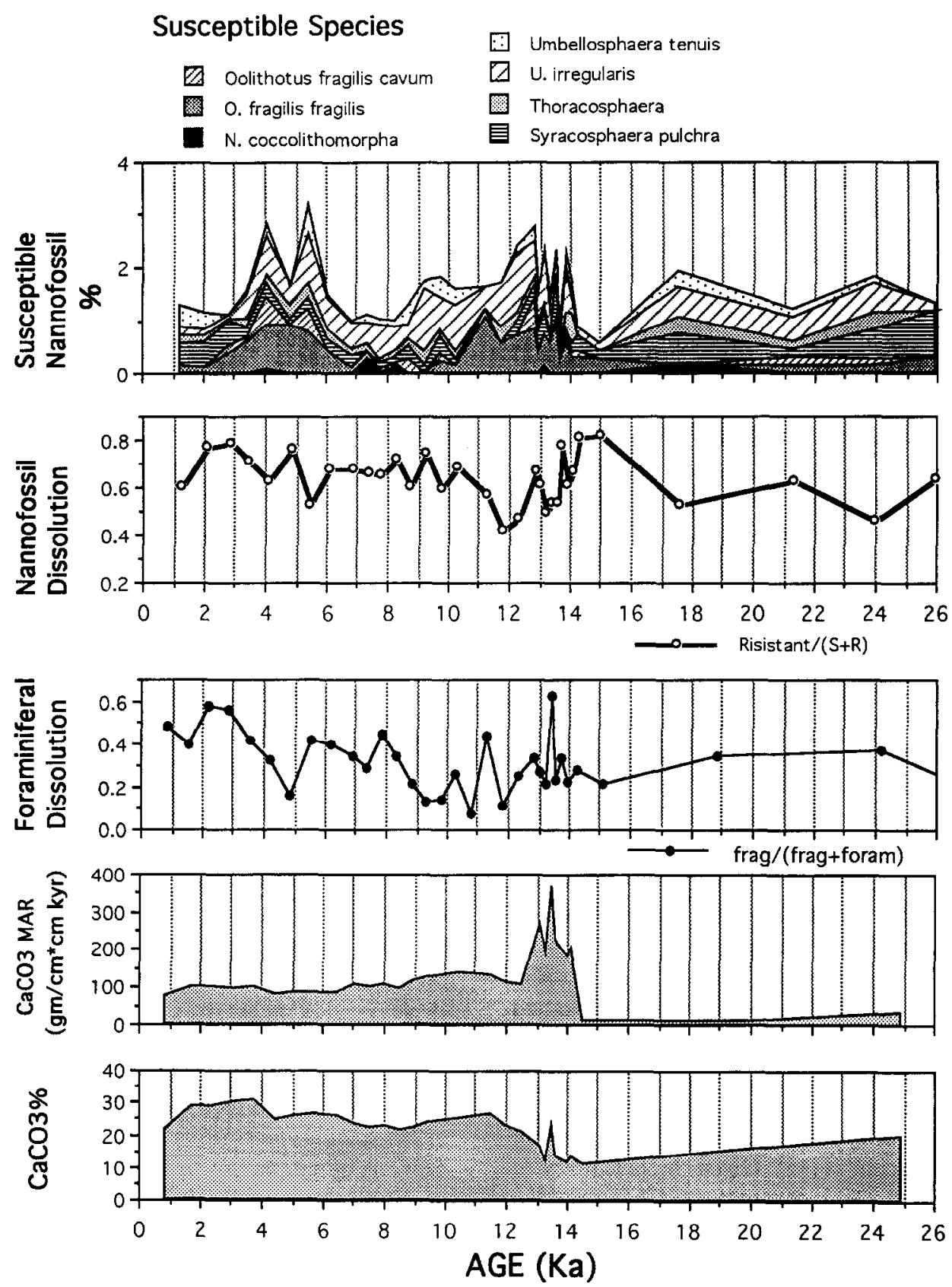

Fig. 5. Summary of microfossil indicators of carbonate dissolution in comparison with down-core variations in $\% \mathrm{CaCO}_{3}$ and $\mathrm{CaCO}_{3}$ mass accumulation rate.

sized G. oceanica during the deglacial stage, and later during the Holocene by small forms, collectively designated as small Gephyrocapsa (cf. Matsuoka and Okada, 1989). This diminution trend is also mirrored by the progressive increase of small placolith forms in the upper section of the core. These small placoliths include Cricolithus jonesi, Crenalithus sp., Dictyococcites, as well as small Reticulofenestra forms such as $R$. minuta (Fig. 4b and Fig. 6). 
$K_{-} Y$. Wei et al./Marine Micropaleontology 32 (1997) 95-114

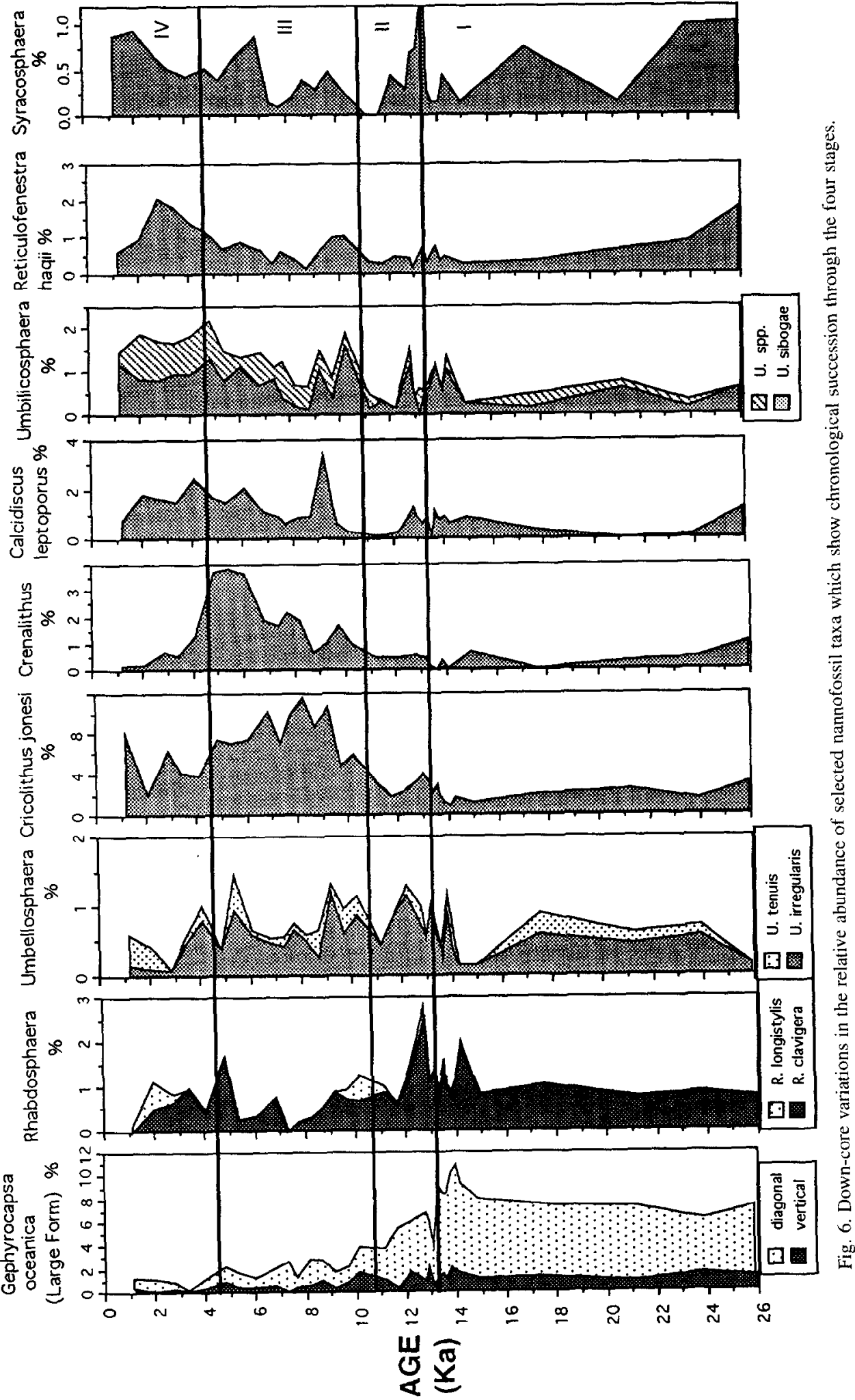




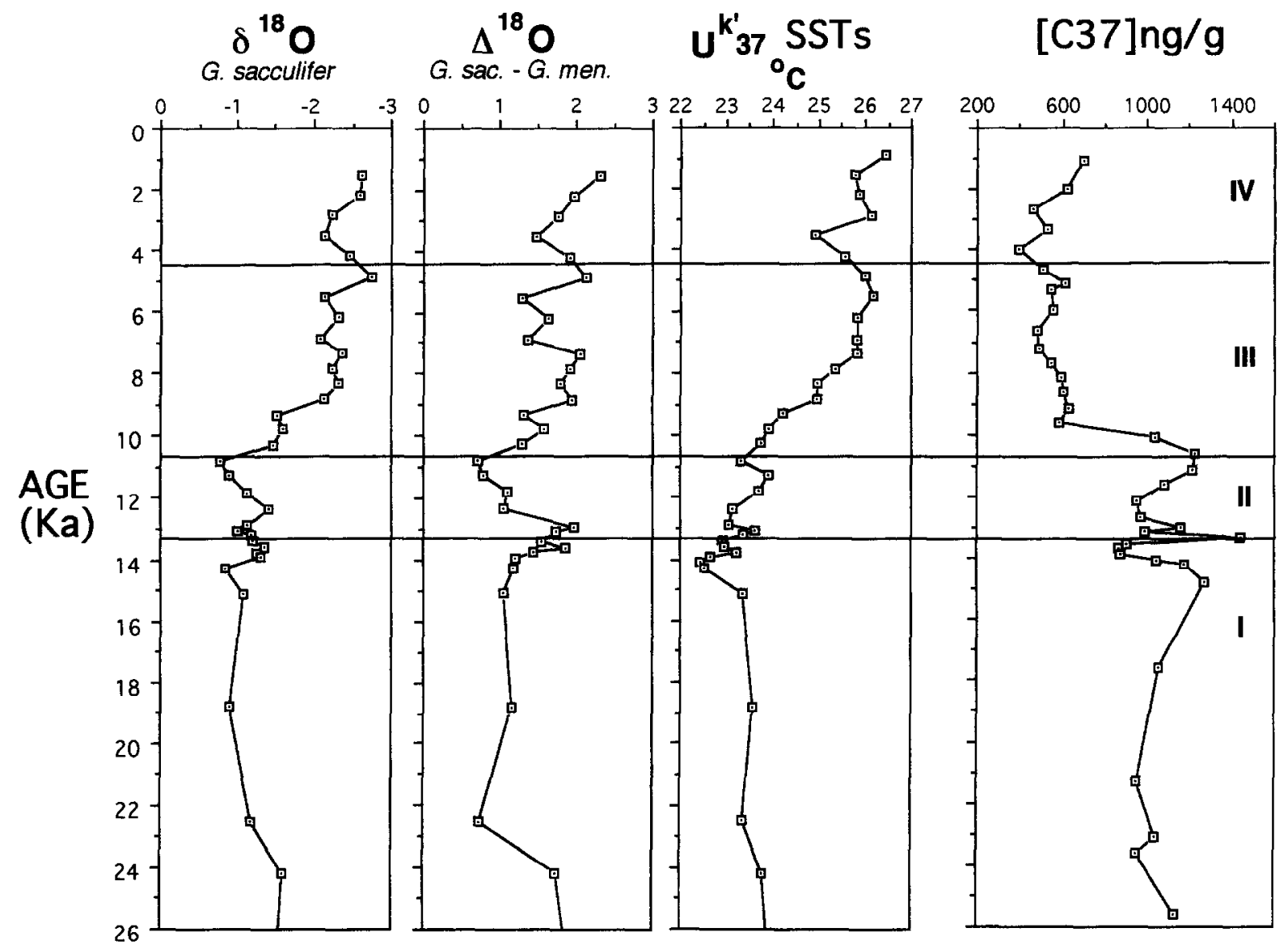

Fig. 7. Time-series of $\delta^{18} \mathrm{O}$ of planktic foraminifera Globigerinoides sacculifer, $\delta^{18} \mathrm{O}$ between surface-dwelling (G. sacculifer) and subsurface-dwelling (Globorotalia manardii) species, sea-surface paleotemperature derived from unsaturation ratio of long-chain methyl alkenones $\left(U_{37}^{\mathrm{k}^{\prime}}\right)$, and ketone $\left(\mathrm{C}_{37}\right)$ concentration. Data are from Huang et al., 1997.

The early Holocene (10.7-4.4 ka) assemblage is dominated by Florisphaera, second by E. huxleyi and third by Gephyrocapsa (Fig. 3). Apparently, the post-deglaciation condition has been more maritime with less terrigenous influence compared to the previous periods. Small placoliths became relatively abundant. These small forms are probably opportunistic elements of the flora. Umbellosphaera, which inhabits tropical oligotrophic pelagic surface waters (McIntyre et al., 1970; Young, 1994), also became relatively more abundant. Such a floral composition indicates that it was a warmer, more maritime, well-stratified oligotrophic environment during the early Holocene. This interpretation is supported by the increase in $\delta^{18} \mathrm{O}$ gradient between the surface water (represented by the planktic foraminifera Glo- bigerinoides sacculifer) and the subsurface water (50-200 m, represented by Globorotalia menardii) (Fig. 7; Huang et al., 1997). This larger gradient is indicative of stronger stratification of the water column. Strong monsoon winds might intermittently deepen the mixed layer and cause nutrient injection into the euphotic zone, inducing blooming of opportunistic species such as small placoliths and $E$. huxleyi.

At about 5.5 and $4.0 \mathrm{ka}$ the preservation of calcareous nannofossils slightly improved. The dissolution index of planktic foraminifera shows also a period of better preservation centered at $5 \mathrm{ka}$ (Fig. 5). This short period predated slightly the episodic cooling of 1 to $2^{\circ} \mathrm{C}$ between 4.5 and $3.0 \mathrm{ka}$ (Fig. 7).

The relative abundances of various small placol- 
iths decreased during the last $4000 \mathrm{yr}$ while that of larger forms such as Calcidiscus leptoporus, $R$. minutula and $R$. haqii increased (Figs. 4 and 6). The vertical $\delta^{18} \mathrm{O}$ gradient also increased (Fig. 7), signifying a more stratified surface-water column. The frequency and/or intensity of seasonal mixing might have become lower, which in turn would have reduced the yield of small placoliths in the flora. By 3 $\mathrm{ka}$, sea surface temperatures had become similar to today's (Fig. 7).

Throughout the core, the variations of nannofossil preservation bear no obvious relationship to the variations in $\mathrm{CaCO}_{3}$ content or $\mathrm{CaCO}_{3}$ accumulation rate (Fig. 5). This suggests that although the preservation of nannofossils may have been governed by the general corrosiveness of the intermediate waters of the SCS, the influence is not necessarily reflected in the accumulation rates of $\mathrm{CaCO}_{3}$ or $\% \mathrm{CaCO}_{3}$. The depth of this site $(2050 \mathrm{~m})$ is slightly above the present nannofossil lysocline $(2300 \mathrm{~m}$, Chen and Shieh, 1982). The nannofossil assemblage therefore is considered to be less sensitive to the glacial deepening of the lysocline and carbonate compensation depth (CCD, at $3000 \mathrm{~m}$ at present and $4000 \mathrm{~m}$ during the LGM; Rottman, 1979; Thunell et al., 1992) than other deeper sites. Owing to this site's proximity to the continent and riverine sediment input sources of the Pearl River (Zhujiang) and the Hanjiang River, the influx of terrestrial sediments is considered to be the primary controlling factor of sedimentation of this site, while the bottom water chemistry is secondary.

\section{Summary and conclusions}

(1) A quantitative study was performed on last glacial to Holocene (25.9-1.2 ka) nannofossils from a piston core collected from the northern South China Sea. Integrated with other proxies, the timeprogressive change in the nannoflora reveals the paleoceanographic evolution of the area since the last glacial.

(2) A detrended correspondence analysis of the nannofloral data suggests that the floral succession can be subdivided into four stages, corresponding to the major paleoceanographic developments in this area: Stage I (25.9--13.3 ka), glacial stage; Stage II (13.3-10.7 ka), deglacial stage; Stage III (10.7-4.4 ka), early Holocene and Stage IV (4.4-1.2 ka), late Holocene.

(3) The glacial stage is characterized by the dominance of Gephyrocapsa and Florisphaera, indicating strong continental influence with high fertility. Good preservation of nannofossil and high concentration of ketone and organic carbon are caused by both high biological productivity and less corrosiveness of the bottom waters.

(4) The increase of E. huxleyi in the deglacial interval suggests an increasing influence of the openocean, corresponding to the global sea-level rise. The decrease of a deep-dwelling taxa, Florisphaera profund $a$, is interpreted as responding to the increased turbidity in surface waters due to the increased input of fine, flushed sediments during the deglacial period by the Continental Coastal Current. A preservation spike of nannofossils centered at $12 \mathrm{ka}$ is also identified.

(5) A time-transgressive diminution trend of Gephyrocapsa existed through the glacial-Holocene, parallel to the decreasing trend of the relative abundance of Gephyrocapsa. This trend is accompanied by the increase of other small placoliths, especially during the Holocene. This might suggest that the NSCS became more maritime and oligotrophic through time, while the surface waters became more stratified as indicated by the increase of the vertical $\delta^{18} \mathrm{O}$ gradient. These small placoliths were opportunistic elements generated during blooming seasons when seasonal mixing of the surface waters took place.

(6) Two episodic cooling events were identified in the post-glacial stages, one at about $11-10 \mathrm{ka}$, the other at 5-3 ka. Both are characterized by better preservation of nannofossil assemblages and a drop in sea-surface paleotemperature of $1-2^{\circ} \mathrm{C}$ as indicated by the $U_{37}^{\mathrm{k}^{\prime}}$ index.

\section{Acknowledgements}

We would like to thank Tom Marchitto, Pinxian Wang, Jeremy Young and an anonymous reviewer for improving the manuscript with their comments and criticisms. This paper is a contribution of the ROC PAGES project. Research funding was provided by Grant No. NSC84-2611-M-002-004GP of the National Science Council, ROC. 

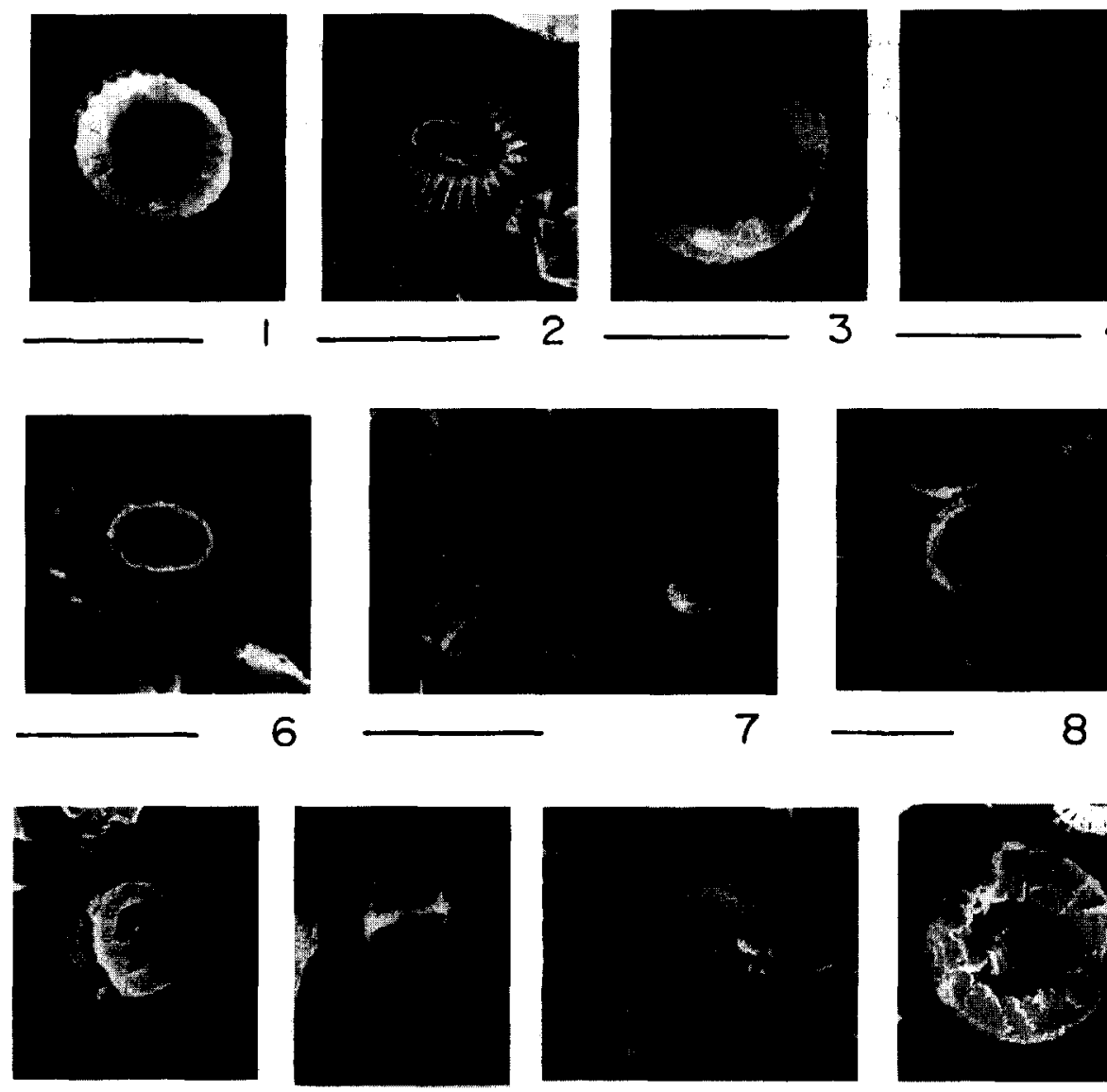

10

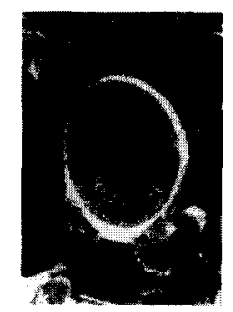

15
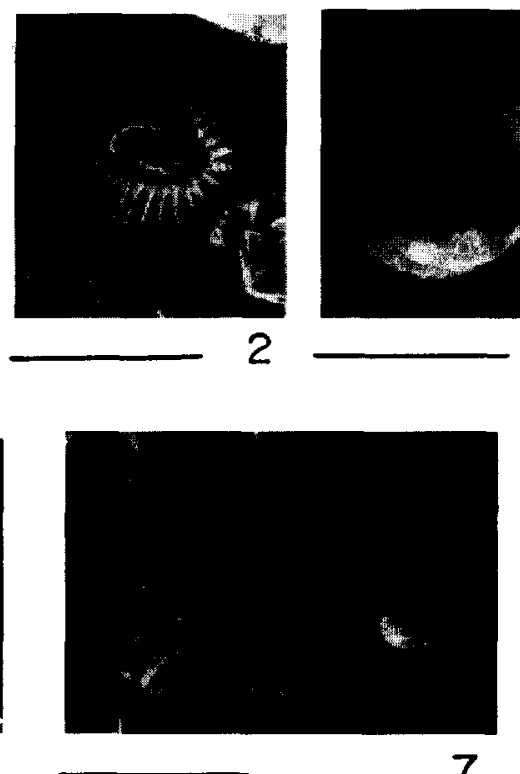

2

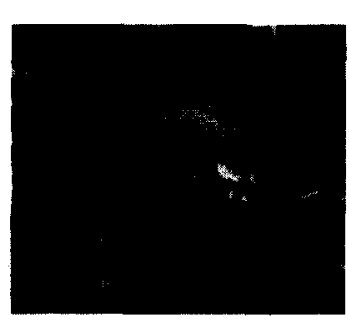

12

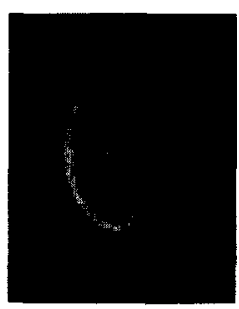

16

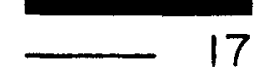

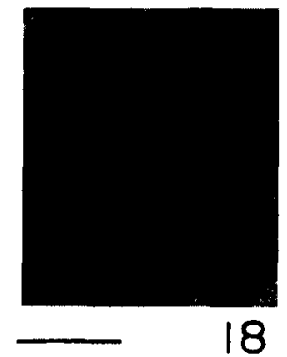

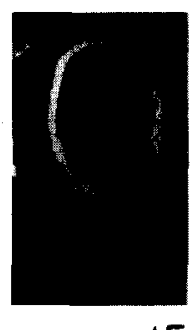

18
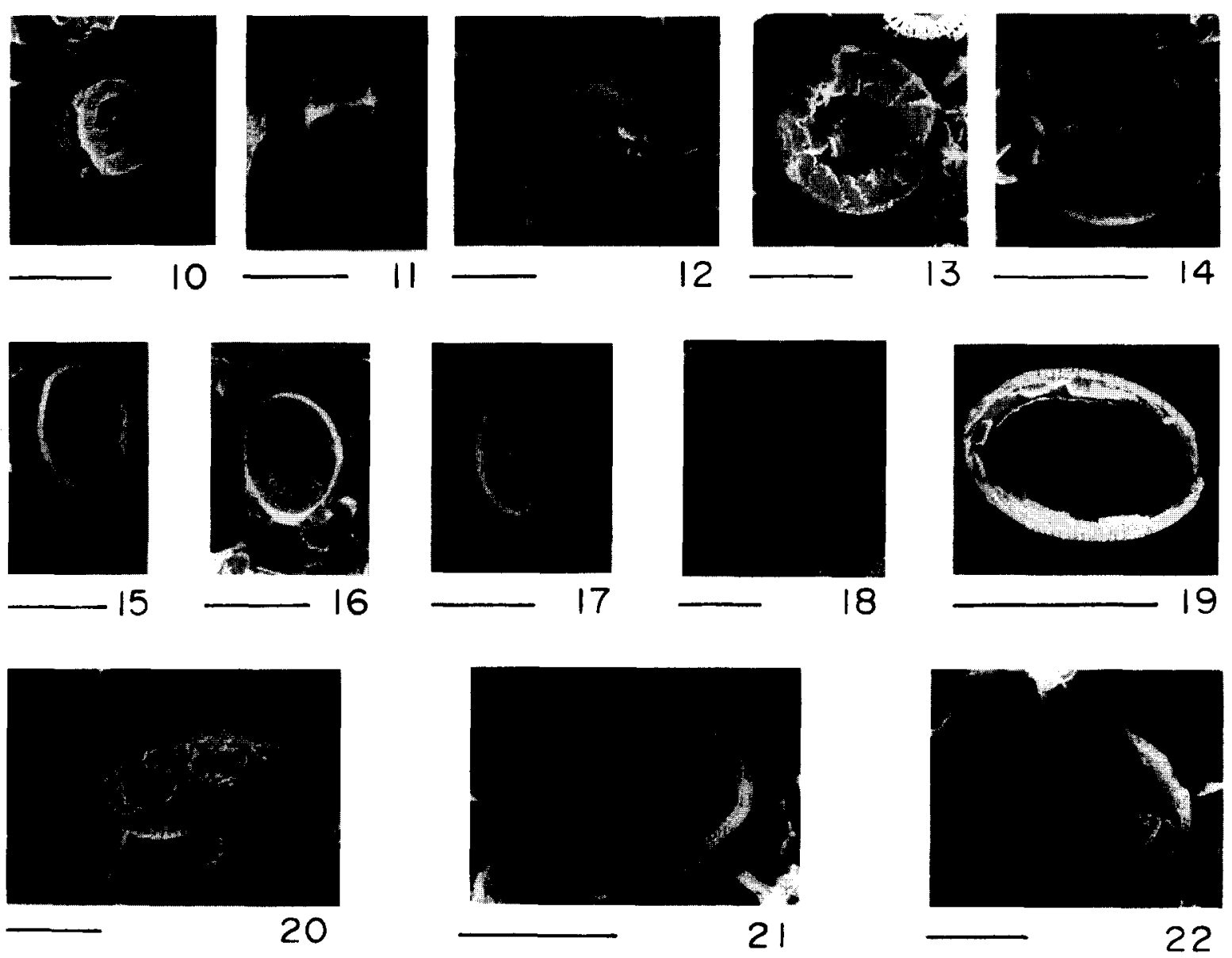

20
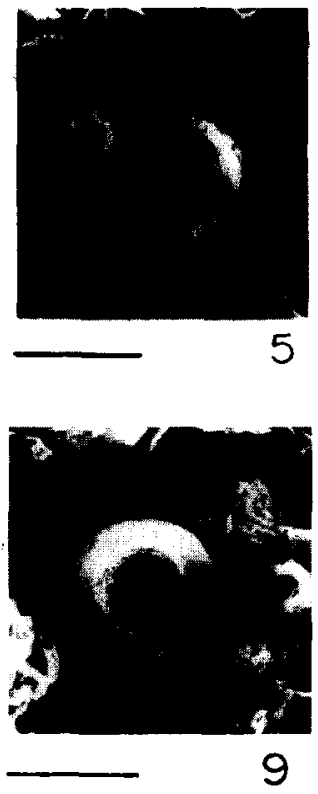

4 


\section{Appendix A. Taxonomic remarks on selected taxa}

Small elliptical placoliths

Small placoliths belonging to Reticulofenestra, Dictyococcites, Gephyrocapsa, Emiliania and Crenalithus are often hard to adequately differentiate under the light microscope due to their small sizes. For the sake of stability and reproducibility of taxonomic identification, we mainly followed strategies outlined

Plate I

Electron micrographs of nannofossils from Core 90-36. Scale bar $=3 \mu \mathrm{m}$.

1. Emiliania huxleyi (Lohmann) Hay and Mohler, proximal view. Subdepth $=17 \mathrm{~cm}$.

2. Emiliania huxleyi (Lohmann) Hay and Mohler, distal view. Subdepth $=17 \mathrm{~cm}$.

3. Reticulofenestra minutula (Gartner) Hay and Berggren, proximal view. Subdepth $=62 \mathrm{~cm}$.

4. Reticulofenestra minuta Roth, proximal view. Subdepth $=62$ $\mathrm{cm}$.

5. Cricolithus jonesi Cohen, distal view. Subdepth $=98 \mathrm{~cm}$.

6. Umbellosphaera irregularis Paasche, proximal view. Subdepth $=62 \mathrm{~cm}$.

7. Umbellosphaera tenuis (Kamptner) Paasche, distal view. Subdepth $=17 \mathrm{~cm}$.

8. Umbilicosphaera sibogae (Weber-van Bosse) Gaarder, distal view. Subdepth $=8 \mathrm{~cm}$.

9. Umbilicosphaera sibogae (Weber-van Bosse) Gaarder, proximal view. Subdepth $=44 \mathrm{~cm}$.

10. Gephyrocapsa oceanica Kamptner (mediun-sized, diagonal bar), distal view. Subdepth $=17 \mathrm{~cm}$.

11. Gephyrocapsa oceanica Kamptner (medium-sized, vertical bar), distal view. Subdepth $=17 \mathrm{~cm}$.

12. Calcidiscus leptoporus (Murray and Blackman) Loeblich and Tappan, proximal view. Subdepth $=98 \mathrm{~cm}$.

13. Oolithotus fragilis (Lohmann) Okada and McIntyre, distal view. Subdepth $=17 \mathrm{~cm}$.

14. Oolithotus fragilis (Lohmann) Okada and McIntyre, proximal view. Subdepth $=98 \mathrm{~cm}$.

15. Syracosphaera pulchra Lohmann. distal view. Subdepth $=$ $98 \mathrm{~cm}$.

16. Syracosphaera lamina Lecal-Schlauder, proximal view. Subdepth $=17 \mathrm{cml}$.

17. Syracosphaera lamina Lecal-Schlauder, distal view. Subdepth $=17 \mathrm{~cm}$.

18. Syracosphaera sp. distal view. Subdepth $=98 \mathrm{~cm}$.

19. Syracosphaera mediterranea Lohmann, distal view. Subdepth $=62 \mathrm{~cm}$.

20. Helicosphaera carteri carteri, (Wallich) Kamptner, distal view. Subdepth $=44 \mathrm{~cm}$.

21. Helicosphaera carteri hyalina, proximal view. Subdepth $=$ $44 \mathrm{~cm}$.

22. Helicosphaera carteri wallichii (Lohmann) Okada and McIntyre, proximal view. Subdepth $=44 \mathrm{~cm}$. by Rahman and Roth (1989), Matsuoka and Okada (1989) and Biekart (1989). The common spirit of these taxonomic schemes is their simplicity and practicality. Differentiation of the various genera is based on features that are recognizable under the light microscope, such as the overall size, presence/absence of a bridge, relative size of the central opening and extinction pattern under crossed-nicols

Elliptical placoliths showing the typical extinction pattern of Gephyrocapsa but without visible bridges were counted as species of Reticulofenestra and Dictyococcites. Specimens with a more or less open central area were assigned to Reticulofenestra, while those with a completely closed central area were identified as Dictyococcites (Matsuoka and Okada, 1989). Two Dictyococcites species were recognized based upon size criteria (Backman, 1980; Matsuoka and Okada, 1989): D. productus (smaller than 4 $\mu \mathrm{m}$ ) and $D$. perplexa (larger than $4 \mu \mathrm{m}=D$, antarticus Haq, 1976).

Forms smaller than $4 \mu \mathrm{m}$ showing a bright inner rim and faint birefringence along the outer margin were considered to be Emiliania huxleyi. The slits between the 'T-shaped' elements on the distal shield are often visible under parallel nicols. However, small etched specimens of Reticulofenestra and Dictyococcites, as well as Gephyrocapsa with its bridge totally dissolved, may possibly be mis-identified as $E$. huxleyi. Forms similar to $E$. huxleyi in size, but showing stronger birefringence and a similar extinction pattern to that of Reticulofenestra, are considered to be Crenalithus sp. (Chen, 1978). For some authors, however, Crenalithus is considered to be a synonym of Reticulofenestra (Backman, 1980) or Dictyococcites (Biekart, 1989) (discussed later).

Forms close in size to $R$. minutula but showing a large central opening surrounded by a narrow rim of strong birefringence were designated as Cricolithus jonesi (Cohen, 1965; Chen, 1978, 1979). However, dissolved small syracosphaerids might be mistaken for this species under the light microscope.

\section{Crenalithus and Reticulofenestra}

Roth (1973) erected the genus Crenalithus for the small elliptical placolith with the type species originally described as Coccolithus doronicoides Black and Barnes (1961). This genus is characterized by its small size, serrate margin and non-imbricated elements in the distal shield. From observation of recent coccolithophorids, Okada and McIntyre (1979) adopted the concept of this genus and erected new species and subspecies, $C$. parvulus parvulus, $C$. parvulus tecticentrum, $C$. punctatus and C. sessilis. They considered these living species to resemble the extinct C. doronicoides. Nishida (1979) and Steinmetz (1991) also reported living Crenalithus species. The proximal side of the central area of these living Crenalithus species is covered by either a solid plate or reticulate grid.

In this study, we classified those specimens which resemble R. minuta but with a larger central opening as Crenalithus sp. (sensu Chen, 1978). However, these Crenalithus forms should considered as small Reticulofenestra if one follows Backman's argument (Backman, 1980). These forms are also possibly some dissolved forms of Dictyococcites productus.

Our purpose is not to resolve the systematics problem dis- 

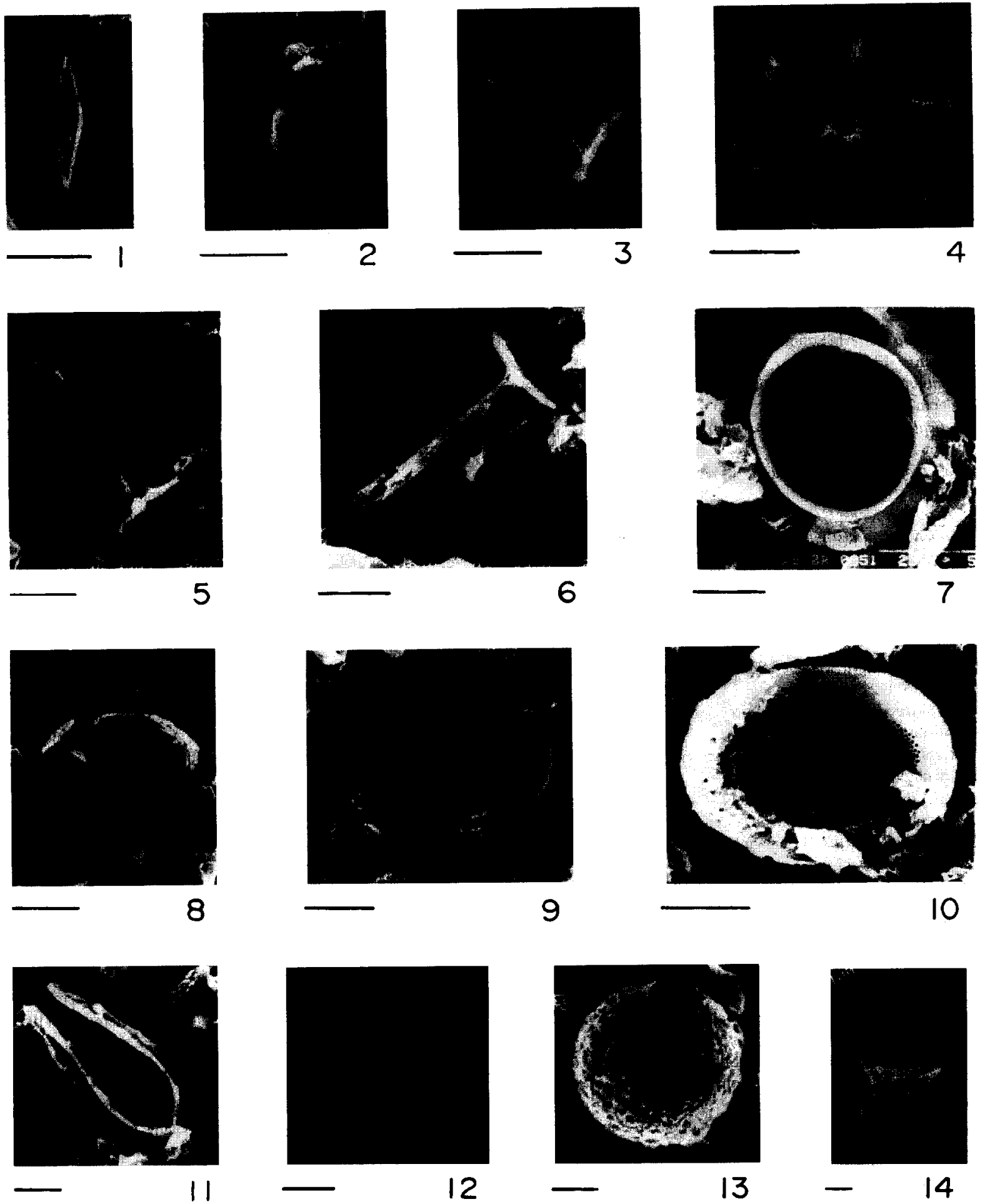

11

12

13

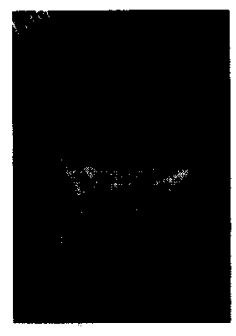

14 
cussed above, instead, we tried merely to differentiate as many forms as possible to explore the paleoenvironmental significance of these small placoliths. Therefore, we tentatively retain the species concept of Crenalithus sp. proposed by Chen (1978) to encompass all the small elliptical placoliths $(<3 \mu \mathrm{m})$ that have a large central opening and show a thin rim resembling the extinction pattern of Reticulofenestra under crossed polarized light. We observed that such forms do exist in our samples and they could be consistently differentiated from other reported Reticulofenestra and Dictyococcites species, although the true identities of these Crenalithus awaits further detailed study.

Crenalithus sp. Chen (Plate III, 16)

Basionym: Chen, 1978, p. 139, pl. 4, figs. 1-2.

Remarks: Small elliptical placolith $(<3 \mu \mathrm{m})$ with non-imbricated or slightly overlapping elements. Under scanning electron microscope, it shows a smooth surface with little relief on the distal side. The elements are relatively wide and show a serrate margin. Central area is open. Under crossed polarized light, it

\section{Plate II}

Electron micrographs of nannofossils from Core 90-36. Scale bar $=3 \mu \mathrm{m}$.

1. Calciosolenia murrayi Gran. Subdepth $=17 \mathrm{~cm}$.

2. Florisphaera profunda elongata (the larger one) and Florisphaera profunda profunda (the smaller one). Subdepth $=17 \mathrm{~cm}$.

3. Discosphaera tubifera (Murray and Blackman) Ostenfeld. Subdepth $=98 \mathrm{~cm}$.

4. Discoaster sp. reworked. Subdepth $=62 \mathrm{~cm}$.

5. Rhabodosphaera clavigera Murray and Blackman. Subdepth $=44 \mathrm{~cm}$.

6. Rhabdosphaera clavigera Murray and Blackman. Subdepth = $62 \mathrm{~cm}$.

7. Neosphaera coccolithomorpha Lecal-Schlauder, distal view. Subdepth $=17 \mathrm{~cm}$.

8. Pontosphaera multipora (Kamptner) Roth, distal view. Subdepth $=17 \mathrm{~cm}$.

9. Pontosphaera discopora Schiller. Subdepth $=98 \mathrm{~cm}$.

10. Pontosphaera japonica (Takayama) Nishida, proximal view. Subdepth $=98 \mathrm{~cm}$.

11. Ceratolithus cristatus Kamptner. Subdepth $=62 \mathrm{~cm}$.

12. Coccosphere of Gephyrocapsa oceanica Kamptner. Subdepth $=98 \mathrm{~cm}$.

13. Thoracosphaera heimii (Lohmann) Kamptner. Subdepth $=$ $62 \mathrm{~cm}$.

14. Scyphosphaera sp. Subdepth $=98 \mathrm{~cm}$. Backman (1980) considered Crenalithus to be a junior synonym of the genus Reticulofenestra. Ile rejected the spccific cpithet doronicoides and identified three species of small Reticulofenestra for the late Neogene: $R$. minutula (3-5 $\mu \mathrm{m}$ with a relatively large central opening), $R$. haqii (3-5 $\mu \mathrm{m}$ with a relatively smaller central opening) and $R$. minuta $(<3 \mu \mathrm{m})$. We did not differentiate $R$. parvula $(<2 \mu \mathrm{m}$ in size $=$ Crenalithus parvulus Okada and McIntyre, 1979, sensu Biekart, 1989) from R. minuta. shows a bright rim with an extinction pattern resembling that of Reticulofenestra. It differs from Diclyococciles productus and Reticulofenestra minuta by its open central area and narrow rim. It is distinguished from Gephyrocapsa by lacking a crossbar in the central opening.

Cricolithus jonesi Cohen (Plate I, 5; Plate III, 10)

Basionym: Cricolithus jonesi Cohen, 1965, p. 16, pl. 2, figs. J. K; pl. 16, figs. a-c.

References: Chen, 1978, p. 140, pl. 5, figs. 1-3; Chen, 1979 , fig. 5; Chen and Shich, 1982, pl. 1, figs. 5-8.

\section{Gephyrocapsa}

The proliferation of taxa assigned to the genus Gephyrocapsa and the associated variable concepts of species have caused a lot of controversies among specialists (Rahman and Roth, 1989; Matsuoka and Okada, 1989; Biekart, 1989). One of the problems associated with this group is the small size of its various forms such that the morphological characteristics of many species/subspecies are only recognizable under the scanning electron microscope. To facilitate a stable taxonomic practice under the light microscope, we have adopted the size criteria of Matsuoka and Okada (1989) to classify the Gephyrocapsa into three size classes: large forms (maximum diameter $>5$ $\mu \mathrm{m}$ ), medium forms (between 5 and $2.5 \mu \mathrm{m}$ ) and small forms $(<2.5 \mu \mathrm{m})$. Medium and large Gephyrocapsa were classified as $G$. caribbeanica or $G$. oceanica. The former has a smaller central area spanned by a robust bridge, whereas $G$. oceanica has a relatively larger central opening. Specimens of $G$. oceanica were further assigned into two varieties: one with a verlically oriented bridge against the vertical axis and the other with a diagonally oriented bridge. The large $G$. oceanica with a diagonal bridge [abbreviated as $G$. oceanica (large, diagonal)] is similar to $G$. lumina Bukry (1973) while the large G. oceanica (vertical) is close to G. omega Bukry (1973). All small Gephyrocapsa forms were lumped as small Gephyrocapsa without further splitting. Some of these small Gephyrocapsa specimens, however, can be easily identified as $G$. ericsonii.

\section{Genus Helicosphaera Kamptner, 1954}

Some authors have proposed that Helicosphaera wallichii and $H$. hyalina should be regarded as varieties of $H$. carteri (Theodoridis, 1984, Okada, 1992). We followed the decision made in the Florence Meeting of INA to include these forms as intraspecific varieties of $\mathrm{H}$. carteri (Jordan and Young, 1990). Three varieties have been recognized as shown in Plates I and IV.

Reticulofenestra minuta Roth (Plate I, 4)

Basionym: Reticulofenestra minuta Roth, 1970, p. 850, pl. 5 , figs. $3,4$.

Synonyms: Dictyococcites minutus (Haq) Haq, Lohmann and Wise, 1976, p. 759. Gephyrocapsa doronicoides (Black and Barnes) var. 4 Pujos, 1985 , p. 563, pl. 2, fig. 1.

References: Biekart, 1989, pl. 1, fig. 4a, b; pl. 6, fig. 6a-c; pl. 7, fig. 2a, b. 
$5 \mu \mathrm{m}$

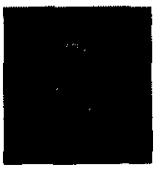

10

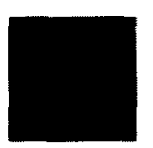

$5 a$

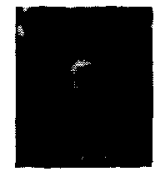

IIa

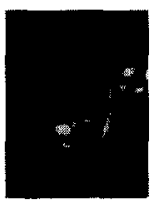

17

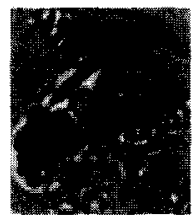

220

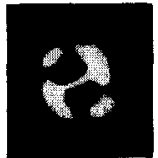

I b

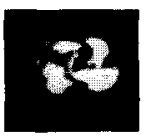

$5 b$

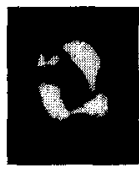

I b

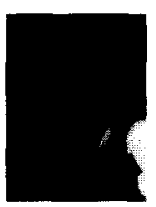

18

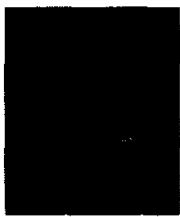

$22 b$

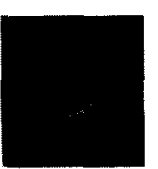

$2 a$

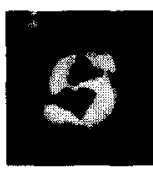

$2 b$

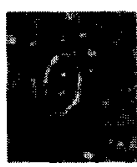

$3 a$

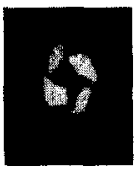

$3 b$

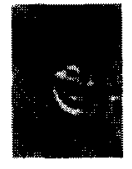

40

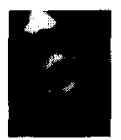

8

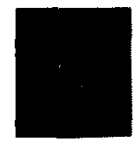

9

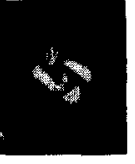

$4 b$

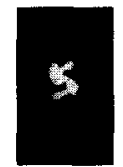

15
$12 \quad 13$

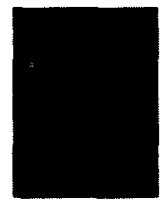

190

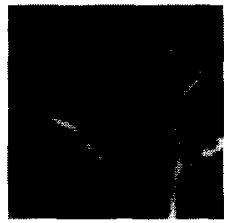

$23 a$

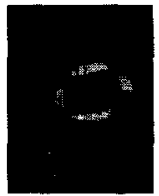

$19 b$

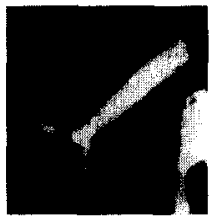

$23 b$
14

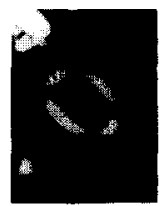

20

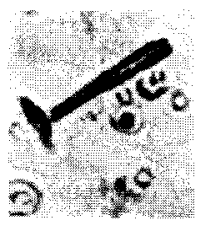

240
16

10
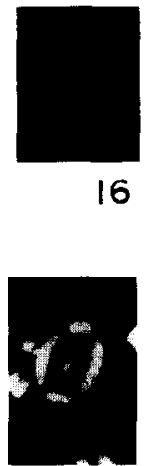

21

Plate III

Optical micrographs of nannofossils from Core 90-36. Scale bar $=5 \mu \mathrm{m}$.

1. Gephyrocapsa oceanica Kamptner (large-sized, vertical bar). Subdepth $=62 \mathrm{~cm}$. (a) Transmitted light. (b) Cross-polarized light.

2. Gephyrocapsa oceanica Kamptner (large-sized, diagonal bar). Subdepth $=62 \mathrm{~cm}$. (a) Transmitted light. (b) Cross-polarized light.

3. Gephyrocapsa oceanica Kamptner (medium-sized, vertical bar). Subdepth $=62 \mathrm{~cm}$. (a) Transmitted light. (b) Cross-polarized light.

4. Gephyrocapsa oceanica Kamptner (medium-sized, diagonal bar). Subdepth $=62 \mathrm{~cm}$. (a) Transmitted light. (b) Cross-polarized light.

5. Gephyrocapsa caribbeanica Bordeaux and Hay. Subdepth $=62 \mathrm{~cm}$. (a) Transmitted light. (b) Cross-polarized light.

6. Small Gephyrocapsa sp. Subdepth $=62 \mathrm{~cm}$. Cross-polarized light.

7. Small Gephyrocapsa spp. (the small one $=$ Gephyrocapsa ericsonii McIntyre and Be). Subdepth $=62 \mathrm{~cm}$. Cross-polarized light.

8. Emiliania huxleyi (Lohmann) Hay and Mohler. Subdepth $=62 \mathrm{~cm}$. Cross-polarized light.

9. Emiliania huxleyi (Lohmann) Hay and Mohler. Subdepth $=62 \mathrm{~cm}$. Cross-polarized light.

10. Cricolithus jonesi Cohen. Subdepth $=62 \mathrm{~cm}$. Cross-polarized light.

11. Reticulofenestra minutula (Gartner) Haq and Berggren. Subdepth $=62 \mathrm{~cm}$. (a) Transmitted light. (b) Cross-polarized light.

12. Reticulofenestra haqii Backman. Subdepth $=62 \mathrm{~cm}$. Cross-polarized light.

13. Reticulofenestra minuta Roth. Subdepth $=62 \mathrm{~cm}$. Cross-polarized light.

14. Dictyococcites perplexa Burns. Subdepth $=62 \mathrm{~cm}$. Cross-polarized light. 


\section{Syracosphaera}

Gaarder and Heimdal (1977) provided a dctailed rcview of the systematic paleontology of this genus and lucid descriptions of species. We basically adopted their taxonomic scheme except that we followed Jordan and Young (1990) and Jordan and Kleijne (1994) in retaining all Coronosphaera species in the genus Syracosphaera.

\section{References}

Ahagon, N., Tanaka, Y., Ujiie, H., 1993. Florisphaera profunda, a possible nanuoplankton indicalor of late Quaternary changes in sea-water turbidity at the northwestern margin of Pacific. Mar. Micropaleontol. 22, 255-273.

Backman, J., 1980. Miocene-Pliocene nannofossils and sedimentation rates in the Hatton-Rockall Basin, N.E. Atlantic Ocean. Stockholm Contrib. Geol, 36 (1), 91 pp.

Berger, W., 1977. Deep sea carbonate and the deglaciation preservation spike in pteropods and foraminifera. Nature 269 , 301-304.

Biekart, J.W., 1989. The distribution of calcareous nannoplankton in late Quaternary sediments collected by the Snellius II Expedition in some southeast Indonesian basins. Proc. K. Ned. Akad. Wet. Ser. B 92 (2), 77-141.

Black, M., Barnes, B., 1961. Coccoliths and discoasters from the floor of the South Atlantic Ocean. J. R. Microsc. Soc. 80 (2), 137-147.

Boyle, E.A., 1988. The role of vertical chemical fractionation in controlling Late Quaternary atmospheric carbon dioxide. J. Geophys. Res. 93, 15701-15714.

Bukry, D., 1973. Coccolith stratigraphy, eastern equatorial Pacific, Leg 16, Deep Sea Drilling Project. Init. Rep. DSDP 16, 653-711.

Chen, M.-P., 1978. Calcareous Nannoplankton Biostratigraphy

Plate III (continued)

15. Dictyococcites productus (Kamptner) Backman. Subdepth $=$ $62 \mathrm{~cm}$. Cross-polarized light.

16. Crenalithus sp. Subdepth $=62 \mathrm{~cm}$. Cross-polarized light.

17. Syracosphaera histrica Kamptner. Subdepth $=62 \mathrm{~cm}$. Crosspolarized light.

18. Syracosphaera pulchra Lohmann. Subdepth $=26 \mathrm{~cm}$. Crosspolarized light.

19. Syracosphaera sp. Subdepth $=62 \mathrm{~cm}$. (a) Transmitted light. (b) Cross-polarized light.

20. Syracosphaera sp. Subdepth $=23 \mathrm{~cm}$. Cross-polarized light. 21. Syracosphaera lamina Lecal-Schlauder. Subdepth $=26 \mathrm{~cm}$. Cross-polarized light.

22. Discosphaera tubifera (Murray and Blackman) Ostenfeld. Subdepth $=62 \mathrm{~cm}$. (a) Transmitted light. (b) Cross-polarized light.

23. Rhabodosphaera clevigera Murray and Blackman. Subdepth $=62 \mathrm{~cm}$. (a) Transmitted light. (b) Cross-polarized light.

24. Rhabodosphaera clavigera Murray and Blackman. Subdepth $=23 \mathrm{~cm}$. (a) Transmitted light. (b) Cross-polarized light. and Paleoclimatic History of Late Neogene Sediments of the Northem Florida Contimental Shelr. Ph.D. Diss., Texas A\&M Univ., College Station, TX (unpubl.).

Chen, M.-P., 1979. Late Pleistocene calcareous nannoplankton in southern Okinawa Trough. Acta Oceanogr. Taiwan. 10, 95-118.

Chen, M.-P., Huang, C.-K., 1995. The distribution of calcareous nannofossils and grain size in the surface sediments of the East China Sea and their relationship to the current pattern. TAO 6 (1), 129-150.

Chen, M.-P., Shieh, K.-S., 1982. Recent nannofossil assemblages in sediments from Sunda Shelf to abyssal plain, South China Sea. Proc. Nat. Sci. Counc. (Taiwan, ROC) A 6, 250-285.

Cheng, X., 1992. Calcareous nannofossils in surface sediments of the central and northern parts of the South China Sea. J. Micropalaeontol. 11, 167-176.

Chinzei, K., Fujioka, K., Kitazato, H., et al., 1987. Postglacial environmental change of the Pacific Ocean off the coast of central Japan. Mar. Micropaleontol. 11, 273-291.

Cohen, C.L.D., 1965. Coccoliths and discoasters from Adriatic bottom sediments. Leidse Geol. Med. 35, 1-44.

Duplessy, J.C., Delibrias, G., Turon, J.L., Pujol, C., Dupart, J., 1981. Deglacial warming of the northeastern Atlantic Ocean: Correlation with the paleoclimatic evolution of the European continent. Palaeogeogr., Palaeoclimatol., Palaeoecol. 35, 121144.

Fairbanks, R.A., 1989. A 17,000-year glacio-eustatic sea level record: Influence of glacial melting rates on the Younger Dryas event and deep sea circulation. Nature 342, 637-642.

Gaarder, K.R., Heimdal, B.R., 1977. A revision of the genus Syracosphaera Lohmann (Coccolithineae). 'Meteor' Forsch.-Ergeb. D 24, 54-71.

Hergucra, J.C., 1992. Deep-sea benthic foraminiferal and biogenic opal: Glacial to postglacial productivity changes in the western equatorial Pacific. Mar. Micropaleontol. 19, 79-98.

Herguera, J.C., Berger, W.H,, 1991. Paleoproductivity from benthic foraminifera abundance: Glacial to postglacial change in the west-equatorial Pacific. Geology 19, 1173-1176.

Herguera, J.C., Berger, W.H., 1994. Glacial to postglacial drop in productivity in the western equatorial Pacific: Mixing rate vs. nutrient concentrations. Geology 22, 629-632.

Hill, M.O., Gauch, H.G.Jr., 1980. Detrended correspondence analysis: An improved ordination technique. Vegetatio 42 , $47-58$.

Honjo, S., Okada, H., 1974. Community structure of coccolithophores in the photic layer of the mid-Pacific. Micropaleontology 20, 209-230.

Huang, C.-Y., Wu, S.-F., Zhao, M., Chen, M.-T., Wang, C.-H., Tu, X., Yuan, P.B., 1997. Last glacial to interglacial surface ocean variability in the South China Sea: A high-resolution record of sea-surface temperature, productivity, and Southeast Asia monsoon. Mar. Micropaleontol. 32 (1-2) (this volume).

Jordan, R.W., Kleijne, A., 1994. A classification system for living coccolithophores. In: Winter, A., Siesser, W.G. (Eds.), Coccolithophores. Cambridge Univ. Press, Cambridge, pp. 83-105. 
$5 \mu \mathrm{m}$

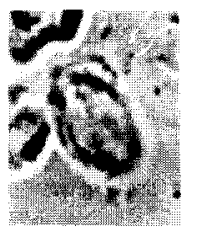

10
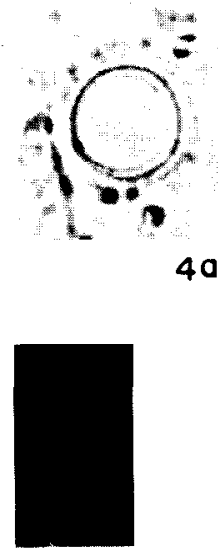

70

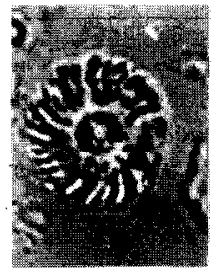

$12 a$

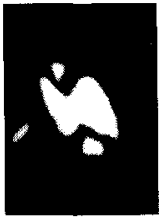

I b

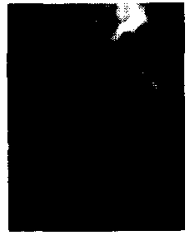

4b

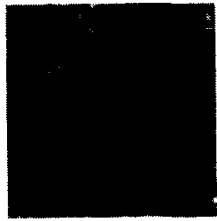

20

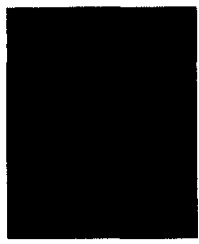

50

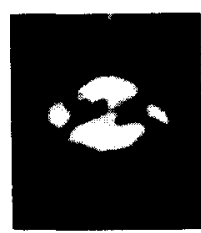

$2 b$

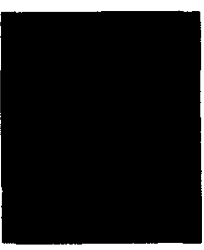

$5 b$

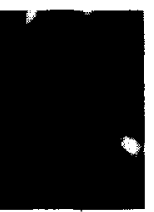

9

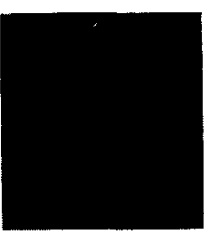

$3 a$

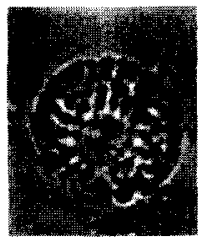

60

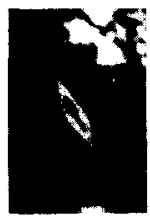

10

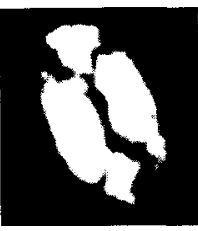

$3 b$

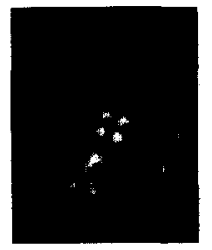

$6 \mathrm{~b}$

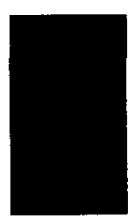

$7 \mathrm{~b}$

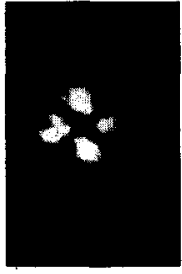

$12 \mathrm{~b}$

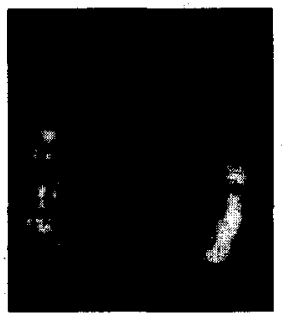

$15 b$

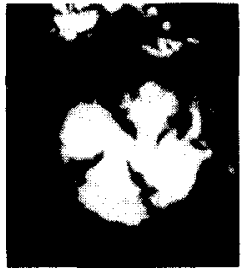

136

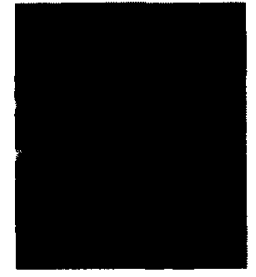

140

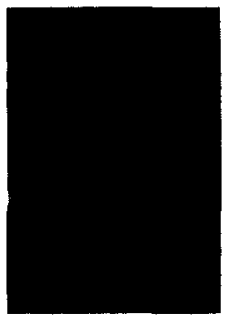

170

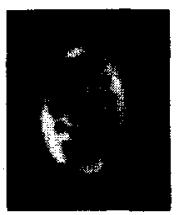

11

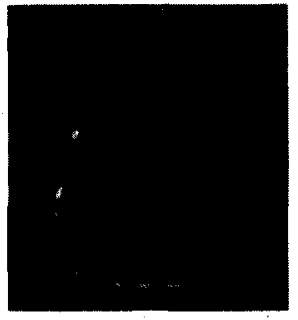

150

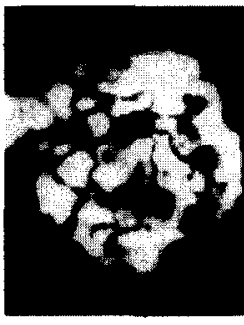

16

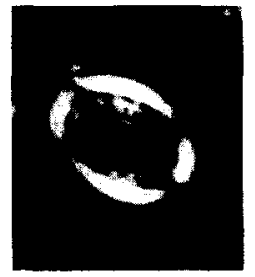

$14 b$

Plate IV

Optical micrographs of nannofossils from Core 90-36. Scale bar $=5 \mu \mathrm{m}$.

1. Helicosphaera carteri hyalina Gaarder. Subdepth $=23 \mathrm{~cm}$. (a) Transmitted light. (b) Cross-polarized light.

2. Helicosphaera carteri wallichii (Lohmann) Okada and McIntyre. Subdepth $=62 \mathrm{~cm}$. (a) Transmitted light. (b) Cross-polarized light.

3. Helicosphaera carteri carteri, (Wallich) Kamptner. Subdepth $=26 \mathrm{~cm}$. (a) Transmitted light. (b) Cross-polarized light. 
Jordan, R.W., Young, J.R., 1990. Proposed changes to the classification system of living coccolithophorids. I.N.A. Newsl. 12 (1), 15-18.

Matsuoka, H., Okada, H., 1989. Quantitative analysis of Quaternary nannoplankton in the subtropical northwestern Pacific Ocean. Mar. Micropaleontol. 14, 97-118.

McIntyre, A., Be, A.W.H., Roche, M.B., 1970. Modern Pacific Coccolithophorida: a paleontological thermometer. Trans. N.Y. Acad. Sci. Ser. II 32 (6), 720-731.

Miao, Q., Thunell, R.C., Anderson, D.M., 1994. Glacial-Holocene carbonate dissolution and sea surface temperatures in the South China and Sulu Seas. Paleoceanography 9, 269-. 290.

Molfino, B., McIntyre, A., 1990a. Precessional forcing of nutricline dynamics in the equatorial Atlantic. Science 249, 766-769 .

Molfino, B., McIntyre, A., 1990b. Nutricline variation in the equatorial Atlantic coincident with the Younger Dryas. Paleoceanography 5, 997-1008.

Moore, T.C., Burckle, L.H., Geitzenauer, K., et al., 1980. The reconstruction of sea surface temperatures in the Pacific Ocean

\section{Plate IV (continued)}

4. Neosphaera coccolithomorpha Lecal-Schlauder, distal view. Subdepth $=26 \mathrm{~cm}$. (a) Transmitted light. (b) Cross-polarized light.

5. Umbellosphaera irregularis Paasche. Subdepth $=62 \mathrm{~cm}$. (a) Transmitted light. (b) Cross-polarized light.

6. Oolithotus fragilis (Lohmann) Okada and McIntyre. Subdepth $=62 \mathrm{~cm}$. (a) Transmitted light. (b) Cross-polarized light.

7. Umbilicosphaera sibogae (Weber-van Bosse) Gaarder. Subdepth $=62 \mathrm{~cm}$. (a) Transmitted light. (b) Cross-polarized light.

8. Umbilicosphaera sibogae (Weber-van Bosse) Gaarder, view. Subdepth $=62 \mathrm{~cm}$. (a) Transmitted light. (b) Cross-polarized light.

9. Florisphaera profunda. Subdepth $=26 \mathrm{~cm}$. Cross-polarizcd light.

10. Calciosolenia murrayi Gran. Subdepth $=26 \mathrm{~cm}$. Crosspolarized light.

11. Pontosphaera multipora (Kamptner) Roth. Subdepth $=62$ cm. (a) Transmitted light. (b) Cross-polarized light.

12. Calcidiscus leptoporus (Murray and Blackman) Loeblich and Tappan. Subdepth $=62 \mathrm{~cm}$. (a) Transmitted light. (b) Crosspolarized light.

13. Calcidiscus macintyrei (Bukry and Bramlette) Loeblich and Tappan. Subdepth $=26 \mathrm{~cm}$. (a) Transmitted light. (b) Crosspolarized light.

14. Pontosphaera discopora Schiller. Subdepth $=23 \mathrm{~cm}$. (a) Transmitted light. (b) Cross-polarized light.

15. Scyphosphaera apsteinii Lohmann. Subdepth $=62 \mathrm{~cm}$. (a) Transmitted light. (b) Cross-polarized light.

16. Thoracosphaera heimii (Lohmann) Kamptner. Subdepth $=$ $26 \mathrm{~cm}$. Cross-polarized light.

17. Pontosphaera japonica (Takayama) Nishida. Subdepth $=23$ $\mathrm{cm}$. (a) Transmitted light. (b) Cross-polarized light. of 18,000 B.P. Mar. Micropaleontol. 5, 215-247.

Nishida, S., 1979. Atlas of Pacific Namoplanktons. News Osaka Micropaleontol. Spec. Pap. 3, 31 pp.

Okada, H., 1983. Modern nannofossil assemblages in sediments of coastal and marginal sea along the Western Pacific Ocean. Utrecht Micropaleontol. Bull. 30, 171-187.

Okada, H., 1992. Biogeographic control of modern nannofossil assemblages in surface sediments of Ise Bay, Mikawa Bay and Kumano-Nada, off coast of central Japan. Mem. Sci. Geol. Padova XLIII, 431-449.

Okada, H., Honjo, S., 1973. The distribution of oceanic coccolithophorids in the Pacific. Deep-Sea Res. 20, 255-274.

Okada, H., McIntyre, A., 1979. Seasonal distribution of modern coccolithophores in the Western North Atlantic Ocean. Mar. Biol. 54, 319-328.

Rahman, A., Roth, P.H., 1989. Late Neogene calcareous nannofossil biostratigraphy of the Gulf of Aden Region. Mar. Micropaleontol. 15, 1-27.

Roth, P., 1973. Calcareous nannofossils - Leg 17, Deep Sea Drilling. Init. Rep. DSDP 17, 695-795.

Roth, P.H., Coulbourn, W.T., 1982. Floral and solution patterns of coccoliths in surface sediments of the North Pacific. Mar. Micropaleontol. 7, 1-52.

Rottman, M.L., 1979. Dissolution of planktonic foraminifera and pteropods in the South China Sea sediments. J. Foraminiferal Res. 9, 41-49.

Steinmetz, J.C., 1991. Calcareous nannoplankton biocoenosis: sediment trap studies in the Equatorial Atlantic, Central Pacific, and Panama Basin. (Ocean Biocoenosis Series, 1.) Woods Hole Oceanogr. Inst., Woods Hole, 85 pp.

Thompson, P.R., 1981. Planktonic foraminifera in the Western North Pacific during the past 150,000 years: Comparison of modern and fossil assemblages. Palaeogeogr., Palaeoclimatol., Palaeoecol. 35, 241-279.

Theodoridis, S., 1984. Calcareous nannofossil biostratigraphy of the Miocene and revision of the helicoliths and discoasters. Utrecht Micropaleontol. Bull. 32, 1-271.

Thunell, R.C., Miao, Q., Calvert, S.E., Pedersen, T.F., 1992. Glacial-Holocene biogenic sedimentation patterns in the South China Sea: Productivity variations and surface water $p_{\mathrm{CO}_{2}}$. Paleoceanography 7, 143-162.

Ujiie, H., Tanaka, Y., Ono, T., 1991. Late Quaternary paleoceanographic record from the middle Ryukyu Trench slope, northwest Pacific. Mar. Micropaleontol. 18, 115-128.

Wang, L., Wang, P., 1990. Late Quaternary Paleoceanography of the South China Sea. Glacial-interglacial contrasts in an enclosed basin. Paleoceanography 5, 77-90.

Wang, P., 1990. The ice-age China Sea - research results and problems. Proc. First Int. Conf. on Asian Marine Geology. China Ocean Press, Beijing, pp. 181-197.

Wang, P., Samtleben, C., 1983. Calcareous nannoplankton in surface sediments of the East China Sea. Mar. Micropaleontol. 8, 249-259.

Wei, K.-Y., Lee, M.-Y,, Duan, W., Chen, C., Wang, C.-H., 1996. Late glacial-Holocene paleoceanography of the northern South China Sea: Core RC26-16. Proc. Int. Symp. Geology Environment, Chiang Mai, pp. 207-219. 
Winter, A., 1982. Paleoenvironmental interpretation of Quaternary coccolith assemblages from the Gulf of 'Aqaba (Elat), Red Sea. Rev. Esp. Micropaleontol. 14, 291-314.

Winter, A., Jordan, R.W., Roth, P.H., 1994. Biogeography of living coccolithophores in ocean waters. In: Winter, A., Siesser,
W.G. (Eds.), Coccolithophores. Cambridge Univ. Press, Cambridge, pp, 161-177.

Young, J.R., 1994. Functions of coccoliths. In: Winter, A., Siesser, W.G. (Eds.), Coccolithophores. Cambridge Univ. Press, Cambridge, pp. 63-82. 